\title{
Language barriers and professional identity: A qualitative interview study of newly employed international medical doctors and Norwegian colleagues
}

Erik Skjeggestad (Corresponding author)

HØKH, Health Services Research Unit

Akershus University Hospital,

Pb.1000, Lørenskog

1478 Lørenskog, Norway

erik.skjeggestad@ahus.no / erik.skjegg@gmail.com

Tlf. +4797545659

Institute of Clinical Medicine

Campus Ahus, University of Oslo

Oslo, Norway

Jennifer Gerwing

HØKH, Health Services Research Unit

Akershus University Hospital

Lørenskog, Norway

Pål Gulbrandsen

Institute of Clinical Medicine

Campus Ahus, University of Oslo

Oslo, Norway

HØKH, Health Services Research Unit

Akershus University Hospital

Lørenskog, Norway

Keywords: International medical graduates (IMGs), cross-cultural teamwork, language barriers, professional identity

Word count: 3834 (Excluding title page, abstract, acknowledgment, references, figures and tables.) 
Objective: To explore how language barriers influence communication and collaboration between newly-employed international medical doctors and Norwegian health personnel.

Methods: Interviews were conducted with 16 doctors who had recently started working in Norway and 12 Norwegian born health personnel who had extensive experience working with international medical doctors. Analyses were consistent with principles of systematic text condensation.

Results: All participants experienced that language barriers caused difficulties in their everyday collaboration. Furthermore, the participants' descriptions of "language barriers" encompassed a wide range of topics, including semantics (e.g., specialized professional vocabulary, system knowledge), pragmatics (e.g., using language in doctor-patient and interprofessional interactions), and specific culturally sensitive topics. All participants described that language barriers provoked uncertainty about a doctor's competence.

Conclusion: Newly employed international medical doctors and their colleagues are concerned by ineffective communication due to language barriers. Experiences of language barriers threaten professional identity as a competent and effective doctor.

Practice implications: Newly employed doctors who are non-native speakers could benefit from support in understanding and handling the array of barriers related to language. 


\section{Introduction}

A significant number of doctors leave their homeland to work in other countries [1,2]. In Norway, approximately $16 \%$ of practicing medical doctors hold foreign citizenship, with international medical graduates (IMGs) comprising a significant proportion of the GP workforce [3] and representing approximately $25 \%$ of senior doctors in hospitals [4]. IMGs have become an important resource for Norwegian health services, similar to other European countries [2], USA, Canada and Australia [1]. Doctors from EU/EEA countries are not subject to national language requirements due to the principle of free movement of labor. Most IMGs in Norway are from Germany and neighboring Scandinavian countries[5]; however, 3.5\% of practicing doctors are from countries outside the EU and must take a high-level Norwegian language examination for authorization. Ultimately, the employer is responsible for ensuring that their healthcare personnel has adequate language skills. Still, IMGs often have some degree of language difficulty, whether they come from countries neighbouring Norway or from ones that are geographically and/or culturally distant [6-9].

International research has shown that IMGs often experience language barriers [7,10-14] and find that their new patients and colleagues have different expectations regarding professional communication compared to what they have learned and practiced in their homeland [6-9,11]. Schwei et al. [15] reviewed the literature regarding language barriers in health care concluding that the topic is well explored and that "researchers worldwide should move away from simply documenting the existence of language barriers". However, they also state, "language barriers adversely affect "quality of care; and patient and provider satisfaction" among other things, calling for more research to understand and rectify such barriers in health services. Indeed, Lineberry's review of educational interventions for IMGs [14] states that the literature on how IMGs learn language skills is insufficient, pointing to a need for interventions to accommodate language barriers.

To understand the implications of practicing health care in a new language, it is important to be aware of the challenges healthcare professionals encounter when immigrating. In general, immigrants report that both the knowledge and the status they had achieved in their home countries have less value in their new countries $[16,17]$. These and other experiences of loss are common, as are a lack of knowledge about their new host country and its health care services [18]. Far from being immune to these challenges, IMGs who begin their careers in a country other than the one in which they were educated find that it can be demanding, and, for some, it can cause emotional stress and loss of self-esteem [10,19-24]. Language barriers and other acculturation stress factors could threaten the IMGs' professional identity. The concept of professional identity (i.e., a person's experience of understanding and mastering his or her profession, possessing adequate knowledge, and applying that knowledge to their work) has become central to medical education [25,26]. A key element of professional identity is the individual's perception of their own professionalism [26] or "sense of being professional" $[25,27]$. This perception is neither inherent to the individual nor static; it is an ongoing 
process [26] related to one's experience of being able to interact effectively with one's environment [28]. In addition, acculturation stress affects the IMGs' ability to adapt to their new surroundings [20], probably including learning a new language and dealing with language barriers.

This study explores the issue of language barriers using semi-structured interviews with newly-employed IMGs and native Norwegian health providers. This study was explorative, aimed at enlightening experiences and views on everyday professional collaboration. A persistent theme was the wide spectra of experiences of language barriers, in particular how these language barriers could influence the IMGs' sense of self and ability to provide quality healthcare.

\section{Methods}

To gain insight into experiences of working relationships between native Norwegian health providers and new IMGs (who would be unfamiliar with the Norwegian health care system and practicing in the Norwegian language), we planned qualitative interviews. Our intention was to work inductively to explore and present health providers' experiences and views about a topic we know concerns health providers, patients, and government administration. We conducted semi-structured interviews that focused on the participant's background, personal experiences of collaboration between IMGs and Norwegian providers, and the meaning people associate with these experiences [29]. Consistent with a phenomenological interview approach, we placed emphasis on the description of specific personal experiences rather than on general comments [30].

\subsection{Participants and data collection}

Twenty-eight participants were recruited: 16 IMGs (who had been working in Norway between a few months and 2 years) and 12 Norwegian medical doctors and nurses who had extensive experience working with IMGs. Participation was anonymous, both because it can be difficult for people to speak freely about sensitive topics, such as experiences and feelings [30] and because the study involved exploration of incidents that health personnel often find difficult to talk about [31]. IMGs were recruited from the National Health Personnel Registry of doctors who had been given Norwegian authorization or license. This also allowed a purposive sampling strategy to ensure sufficient variation on factors that could influence their experience of coming to Norway as an IMG (i.e., participants' age, sex and nationality; see Table 1). Eighteen IMGs were contacted by phone. All were willing to participate; however, two were geographically too far away to participate in a face-toface interview. The remaining 16 IMGs were from all parts of the country and their position ranged from intern to specialist. Other main findings of this IMG study have been published previously [19] with this paper focusing on the aspect of language barriers. 
Table 1: Demographic characteristics of the study sample - IMG participants $(\mathrm{N}=16)$

Nationality (4 reported double citizenship)

\begin{tabular}{|c|c|}
\hline Scandinavian & 4 \\
\hline$\overline{E U}$ & 4 \\
\hline Russia/Former U.S.S.R & 3 \\
\hline South and Central America & 3 \\
\hline Asia & 3 \\
\hline Africa & 2 \\
\hline USA/Australia & 1 \\
\hline \multicolumn{2}{|l|}{ Gender } \\
\hline Women & 9 \\
\hline Men & 7 \\
\hline \multicolumn{2}{|l|}{ Age } \\
\hline $20-30$ & 5 \\
\hline $30-40$ & 8 \\
\hline $40+$ & 3 \\
\hline \multicolumn{2}{|l|}{ Place of work } \\
\hline Public or private hospital (5 different) & 8 \\
\hline General practitioners/municipal health service & 5 \\
\hline $\begin{array}{l}\text { Currently unemployed (Was working in Norway } \\
\text { recently) }\end{array}$ & 3 \\
\hline \multicolumn{2}{|l|}{ Last or current type of position } \\
\hline $\begin{array}{l}\text { Specialty registrar or doctor in the primary } \\
\text { health services }\end{array}$ & 7 \\
\hline Hospital specialist & 5 \\
\hline Foundation doctor & 4 \\
\hline
\end{tabular}

The Norwegian health care professionals were recruited through the researchers' own professional networks. Although not all responded to the initial contact about participation, all 12 who 
did and heard more about the study agreed to participate. This group of colleagues had experience collaborating with several hundred IMGs in different hospitals and community services throughout Norway. For both interview groups, recruitment was stopped when participant diversity was reached in terms of gender, work experience, and place of work (Tables 1 and 2), and when the data collected was deemed to consist of a purposive amount of relevant descriptions.

\begin{tabular}{|l|c|}
\hline \multicolumn{2}{|l|}{ Table 2: Demographic characteristics of the study sample - Colleague participants (N = 12) } \\
\hline Gender & 6 \\
\hline Women & \\
\hline Men & \\
\hline Work experience & \\
\hline More than 10 years & \\
\hline Less than 10 years & \\
\hline Place of work & \\
\hline Public or private hospital (5 different) & \\
\hline General practitioners/municipal health service & \\
\hline Profession & \\
\hline Doctors & \\
\hline Nurses & \\
\hline
\end{tabular}

The first author conducted the interviews, which lasted from 30 to 90 minutes. All interviews were audiotaped and transcribed in full text by first author. After the interviews, participants were given the opportunity to contact the researchers with any supplementary information and to read and comment on their interview transcripts. Data also consisted of the interviewer's notes about topics, such as his experience of the interview and language challenges affecting the interviews.

\subsection{Analysis}

Malterud's method for systematic text condensation (STC) was used, as it is suitable for the analysis of meaning and content [29,32]. STC is inspired by Giorgi's descriptive phenomenological method in psychology [33] and is empirically based and suited for inductive analyses intended to develop descriptions of a field across a dataset. In this case, the field was the experience of being a new IMG in Norway and of collaboration with new IMGs. To ensure quality and trustworthiness in 
the analysis, PG and ES read all transcriptions and met to discuss, code and synthesize results from the interview data, according to the STC method [29,32]. Other researchers (e.g. JG) reviewed analysis to ensure the relevance of the results and to contribute their expertise. Since the data are extensive, comprising many topics, the focus of this paper is limited to participants' explicit descriptions of language and language barriers. Descriptions of these experiences provide valuable, new knowledge about IMGs' language barriers and are thus suitable for the aim of an explorative study. In Malterud's terms: "we do not head for a complete description of all aspects of the phenomenon we study. We are satisfied when a study open some doors to unknown territory by presenting examples that contribute to new understanding”[29].

\subsection{Ethics}

The regional committee of medical and health research ethics deemed that the project did not require a formal submission. The study protocols for data collection and storage were approved by the local data protection officer and written consent was obtained from all the participants.

\section{Results}

\subsection{Overview}

All participants, both IMGs and Norwegian health personnel, spontaneously described language barriers as the most prevalent problem in their everyday collaborations. Indeed, many of the participants brought up the topic at the beginning of the interview, some even before it had formally begun. Further description and specifications of these difficulties revealed a wide spectrum of situations where they had experienced such barriers. An important phenomenon in both IMGs and native Norwegian colleagues' accounts was that the experiences and feelings regarding such barriers were not coherent with their expectations of professional communication.

\subsection{The participants' descriptions of language barriers}

The descriptions of the participants' personal experiences revealed a variety of topics that could be considered language barriers (Table 3), including topics related to proficiency in the Norwegian language (lines 1-4, Table 3). These categories deal with the semantics of language used, both in general (line 1) and in relation to healthcare-specific terminology (lines 2-4). Other challenges were more pragmatically oriented: Lines 5-7 touch on difficulties due to Norwegian patterns of language use that would be needed for doctor-patient interaction and inter-professional communication. These have to do with subtle cues regarding how the semantic content of language is to be understood: Successful use of these cues in interaction tend to be invisible and unnoticed. However, errors in these cues create misunderstandings that tend not to be recognized as linguistic error, but rather can lead participants to see each other as uncooperative, rude, or impertinent $[34 \mathrm{p}$. 132]. Finally, we included a category of language used in culturally sensitive topics (line 8). As can be seen in Table 3, according to our informants, descriptions of these categories was linked to their 
effects, such as, less effective communication, problems with relationship building, and a decreased sense of the professionalism and competence of IMGs.

\begin{tabular}{|c|c|c|c|}
\hline $\begin{array}{l}\text { Topics and } \\
\text { subtopics }\end{array}$ & Description of topic & $\begin{array}{l}\text { Statements from IMG } \\
\text { that fits the topic }\end{array}$ & $\begin{array}{l}\text { Statements from Norwegian } \\
\text { colleagues of IMG that fit each } \\
\text { topic }\end{array}$ \\
\hline \multicolumn{4}{|c|}{ Semantics: Insufficient Norwegian language proficiency } \\
\hline (1) General & $\begin{array}{l}\text { Language barriers due } \\
\text { to lack of general } \\
\text { Norwegian skills (e.g., } \\
\text { vocabulary, } \\
\text { conjunctions, idioms } \\
\text { dialects, accents, } \\
\text { tempo, and intonation) }\end{array}$ & $\begin{array}{l}\text { I think there are many } \\
\text { things that might have } \\
\text { been done faster if I had } \\
\text { spoken better } \\
\text { Norwegian, for instance, } \\
\text { some expressions are } \\
\text { difficult when you are } \\
\text { making phone calls } \\
\text { (Junior IMG from } \\
\text { Scandinavia) }\end{array}$ & $\begin{array}{l}\text { Some can speak Norwegian well, } \\
\text { but they speak so unclearly that } \\
\text { patients have trouble } \\
\text { understanding them. We had a } \\
\text { doctor here who is very skillful, } \\
\text { but he spoke Norwegian too fast } \\
\text { (Nurse in leadership position) }\end{array}$ \\
\hline $\begin{array}{l}\text { (2) Biomedical } \\
\text { Terminology }\end{array}$ & $\begin{array}{l}\text { Language barriers due } \\
\text { to not acquiring } \\
\text { professional } \\
\text { biomedical language } \\
\text { used in Norway (e.g., } \\
\text { use of Latin, or } \\
\text { different names of } \\
\text { medical states and } \\
\text { name of medicines) }\end{array}$ & $\begin{array}{l}\text { I would have supported } \\
\text { medical related } \\
\text { Norwegian courses, also } \\
\text { for us with Scandinavian } \\
\text { background. Language } \\
\text { barriers have not led to } \\
\text { any errors on my part, } \\
\text { but I can see how they } \\
\text { could have done (Senior } \\
\text { IMG from Scandinavia) }\end{array}$ & $\begin{array}{l}\text { Doctors educated abroad have } \\
\text { read all in English and they have } \\
\text { established a professional } \\
\text { terminology, which is in English. } \\
\text { They are not accustomed to speak } \\
\text { about patients in Norwegian with } \\
\text { colleagues. In the beginning, they } \\
\text { have problems with finding the } \\
\text { right word and naming the correct } \\
\text { symptoms (Junior doctor) }\end{array}$ \\
\hline $\begin{array}{l}\text { (3) Discipline- } \\
\text { specific } \\
\text { terminology }\end{array}$ & $\begin{array}{l}\text { Barriers due to lack of } \\
\text { relevant subject-area } \\
\text { language in some } \\
\text { sectors such as } \\
\text { psychiatry, geriatrics, } \\
\text { and general practice }\end{array}$ & $\begin{array}{l}\text { Every day, I am } \\
\text { challenged when I meet } \\
\text { patients because of my } \\
\text { language barriers. } \\
\text { Psychiatry is different } \\
\text { from ordinary medicine; } \\
\text { you have to conduct a } \\
\text { dialog to understand the } \\
\text { patient's illness. In } \\
\text { somatic you have a } \\
\text { stethoscope with a heart } \\
\text { and a stomach to touch } \\
\text { but here there is nothing } \\
\text { to touch or listen to } \\
\text { (Senior IMG from Asia) }\end{array}$ & $\begin{array}{l}\text { A leader tells about a doctor that } \\
\text { she find medical competent to the } \\
\text { job, but who do not have the } \\
\text { suitable practical language skills } \\
\text { to do the job: We have a } \\
\text { medically gifted doctor, a woman } \\
\text { who came from a European } \\
\text { country but she interacts } \\
\text { differently with patients than what } \\
\text { we are used to. She had very good } \\
\text { references from a research } \\
\text { institution but was not trained to } \\
\text { be a general practitioner at all } \\
\text { (Senior doctor in leadership } \\
\text { position) }\end{array}$ \\
\hline $\begin{array}{l}\text { (4) Health and } \\
\text { welfare } \\
\text { System } \\
\text { terminology }\end{array}$ & $\begin{array}{l}\text { Barriers due to lack of } \\
\text { language referring to } \\
\text { the Norwegian health } \\
\text { and welfare system } \\
\text { (e.g., does not know the } \\
\text { name of institutions, } \\
\text { how to describe }\end{array}$ & $\begin{array}{l}\text { How the system works } \\
\text { and which form you have } \\
\text { to use, all such things are } \\
\text { hard when you are new, } \\
\text { not only for foreigners } \\
\text { but also for everyone. } \\
\text { When you are new, you }\end{array}$ & $\begin{array}{l}\text { It is not necessarily about medical } \\
\text { competence, but work related } \\
\text { logistics, patient communication, } \\
\text { language and understanding of the } \\
\text { Norwegian health care system, of } \\
\text { course. When coming from }\end{array}$ \\
\hline
\end{tabular}




\begin{tabular}{|c|c|c|c|}
\hline & $\begin{array}{l}\text { routines, how to } \\
\text { provide system } \\
\text { information). }\end{array}$ & $\begin{array}{l}\text { may also have problems } \\
\text { with communication and } \\
\text { not know how things } \\
\text { work, nobody will tell } \\
\text { you, it is hard then to } \\
\text { understand (Senior IMG, } \\
\text { south/central America) }\end{array}$ & $\begin{array}{l}\text { abroad it is pretty difficult to } \\
\text { work in an unknown, relatively } \\
\text { streamlined Norwegian healthcare } \\
\text { system (Senior doctor) }\end{array}$ \\
\hline \multicolumn{4}{|c|}{ Pragmatics: Using Norwegian language } \\
\hline $\begin{array}{l}\text { (5) for social } \\
\text { relations }\end{array}$ & $\begin{array}{l}\text { Language barriers due } \\
\text { to proficiency levels } \\
\text { impeding good } \\
\text { relations }\end{array}$ & $\begin{array}{l}\text { In the beginning, I cried } \\
\text { several times, I felt } \\
\text { insufficient because of } \\
\text { the language. Normally, } \\
\text { as a doctor I am "easy } \\
\text { going" to break the ice } \\
\text { during a patient visit (...) } \\
\text { but I did not manage to } \\
\text { do that, because of } \\
\text { language barriers all my } \\
\text { personality was lost } \\
\text { (Junior IMG with a } \\
\text { background from both } \\
\text { the EU and Scandinavia) }\end{array}$ & $\begin{array}{l}\text { A psychiatrist tells about what he } \\
\text { has observed in consultations } \\
\text { together with a newly employed } \\
\text { IMG colleague: "I saw that she } \\
\text { did make positive progress, but } \\
\text { the patients were more reticent, } \\
\text { partly because they did not } \\
\text { understand what she said, that } \\
\text { made them insecure" (Senior } \\
\text { doctor) }\end{array}$ \\
\hline $\begin{array}{l}\text { (6) for navigating } \\
\text { and expressing } \\
\text { inter-professional } \\
\text { roles }\end{array}$ & $\begin{array}{l}\text { Barriers due to the lack } \\
\text { of understanding of } \\
\text { sociocultural aspects } \\
\text { that influencing proper } \\
\text { communication with } \\
\text { other healthcare } \\
\text { providers }\end{array}$ & $\begin{array}{l}\text { I said to the nurses "can } \\
\text { you" and ended my } \\
\text { sentences with "please". } \\
\text { However, the way I } \\
\text { formulated my questions } \\
\text { were understood as } \\
\text { commands. They thought } \\
\text { that I instructed them to } \\
\text { do things like take blood } \\
\text { pressure at once, which } \\
\text { made them complain. It } \\
\text { was very difficult in the } \\
\text { beginning (Senior IMG } \\
\text { from Asia) }\end{array}$ & $\begin{array}{l}\text { I think some felt that we had an } \\
\text { informal tone between us. You } \\
\text { probably do not have to travel } \\
\text { farther than to our neighboring } \\
\text { countries to meet nurses that treat } \\
\text { the doctor with different respect } \\
\text { and form of address than we } \\
\text { practice here. However, when } \\
\text { they have been here for a while } \\
\text { the impression is that they realize } \\
\text { that they have professional } \\
\text { respect even if we have a } \\
\text { communication form that is a bit } \\
\text { more "hey you!" That could be } \\
\text { difficult to grasp, it could be } \\
\text { understood as "I am not } \\
\text { respected", a few times some of } \\
\text { them responded with signals of "I } \\
\text { want respect" (Senior Doctor in } \\
\text { leadership position) }\end{array}$ \\
\hline $\begin{array}{l}\text { (7) for navigating } \\
\text { and expressing } \\
\text { doctor and patient } \\
\text { roles }\end{array}$ & $\begin{array}{l}\text { Language barriers due } \\
\text { to role expectations of } \\
\text { both the doctor and } \\
\text { patient }\end{array}$ & $\begin{array}{l}\text { I have learned from my } \\
\text { colleagues how to } \\
\text { communicate with } \\
\text { patients, learning how to } \\
\text { deliver bad news to a } \\
\text { patient. After I started to } \\
\text { work at this hospital, I } \\
\text { also learned which } \\
\text { information that should } \\
\text { be given to which } \\
\text { relatives. (Senior IMG } \\
\text { from Asia) }\end{array}$ & $\begin{array}{l}\text { A nurse tells about an IMG } \\
\text { colleague from a European } \\
\text { country that told her: "I have to } \\
\text { learn to speak differently to the } \\
\text { patients here because you speak } \\
\text { so kindly to the patients. In my } \\
\text { homeland, if the patient had been } \\
\text { angry I would have said "You can } \\
\text { go, if you do not want to do as I } \\
\text { say, you can just go." I have to }\end{array}$ \\
\hline
\end{tabular}




\begin{tabular}{|c|c|c|c|}
\hline & & & $\begin{array}{l}\text { communicate differently, bearing } \\
\text { in mind that the patient makes } \\
\text { demands and may have } \\
\text { knowledge about their condition. } \\
\text { In my homeland, the doctor is the } \\
\text { one with knowledge." (Nurse in a } \\
\text { leadership position) }\end{array}$ \\
\hline \multicolumn{4}{|c|}{ Language associated with cultural context } \\
\hline $\begin{array}{l}\text { (8) Sensitive } \\
\text { topics }\end{array}$ & $\begin{array}{l}\text { Barriers due to lack of } \\
\text { acquiring "ritual } \\
\text { language", i.e., culture } \\
\text { related patterns of } \\
\text { communication in } \\
\text { particular missed in } \\
\text { sensitive situations } \\
\text { (e.g., around death, } \\
\text { sexual health and } \\
\text { orientation) }\end{array}$ & $\begin{array}{l}\text { Once I had to verify a } \\
\text { death, there were many } \\
\text { relatives and I had very } \\
\text { little to say but I wanted } \\
\text { to show sympathy, but I } \\
\text { did not know what to } \\
\text { say. It was so difficult, I } \\
\text { did not do anything } \\
\text { wrong, but it was hard to } \\
\text { talk to the relatives. } \\
\text { What should I say? } \\
\text { (Junior IMG from Asia) }\end{array}$ & $\begin{array}{l}\text { A colleague described how a } \\
\text { senior IMG came into a room of } \\
\text { relatives together with a patient } \\
\text { who recently passed away: "He } \\
\text { comes into the room, he pulls out } \\
\text { the medical chart, turned on his } \\
\text { heel and left the room without any } \\
\text { communication with the relatives; } \\
\text { that seems to be really wrong in } \\
\text { that situation" (Senior doctor) }\end{array}$ \\
\hline \multicolumn{4}{|c|}{$\begin{array}{l}\text { * Statements are translated from Norwegian to English and edited for readability by the authors. Presented } \\
\text { examples are illustrative excerpts from longer statements of from when participants described language- } \\
\text { relevant topics. }\end{array}$} \\
\hline
\end{tabular}

The participants reported that learning to communicate as a Norwegian doctor is an individual process (i.e., without organized support); that is, it was the individual's responsibility to learn the language adequately, with little direction as to what should be considered "adequate". Neither IMGs nor native Norwegian professionals were clear about whether the IMGs' mother tongue and nationality had an impact on the severity of communication barriers they experienced. However, IMGs from neighboring Scandinavian countries expressed that they found the differences between languages more extensive than they had anticipated. ${ }^{1}$ Many reported language challenges and uncertainty about how to improve them. Colleagues confirmed that IMGs had to take responsibility for learning the language themselves and described how some IMGs struggled, while others became competent in Norwegian quickly.

\subsection{Meeting one's own and others' expectations of professional communication}

Participants' views of what constitutes a well-functioning doctor were often related to mastering communication with patients. One IMG, who did not speak Norwegian as well as she desired, lost confidence in herself as a professional communicator: "I am not myself when I speak Norwegian. I enjoyed communicating with patients in my homeland. That may be one reason why I do not thrive as a doctor in Norway. I'm losing what for me was a big part of what I liked about the job:

\footnotetext{
${ }^{1}$ Scandinavian languages are closely interrelated, and when visiting one of the other Scandinavian countries you can usually get by as a tourist using your own language.
} 
the fact that I thought I was a good communicator" (Junior IMG, from an English speaking country outside the EU). Several IMGs were concerned that their patients and colleagues might find them cold and insensitive because they did not manage relationship and communication skills as effectively as they desired. Among the IMGs, language difficulties caused them to avoid communication with both patients and colleagues. A Scandinavian male doctor illustrated this passivity: "When I sit there in the morning briefing and have something I really want to say, but do not dare, I am afraid of not being understood. I am afraid to say something wrong; it had been wonderful to just say things straight out and know it was understood" (Senior IMG, from a Scandinavian country). The majority of IMGs stated that they avoided tasks that they thought would be overly difficult because of their insufficient language skills (e.g., telephone calls). Some participants also described situations in which they were aware that they not had understood what had been said, but had not been forthcoming about it.

Most of the IMGs were concerned about patients' reactions to their language skills. Several IMGs reported that they were regularly asked about where they were from; some found this difficult, as it took a considerable amount of time to answer and detracted from the purpose of the consultation. IMGs also described such questions as stressful reminders that their language and communication skills might be inadequate. A GP said she noticed that patients were surprised when they heard her accent, often asking her where she was from: "When I tell them where I come from, people become surprised and some less accommodating. I think it has something to do with bad descriptions in the media about my homeland and the political situation there. There have been no personal insults, but there are patients who are mentally unstable, but you learn to deal with such patients" (Senior IMG, from the EU). Generally, the IMGs described Norwegian patients as benevolent and not xenophobic. When conflicts occurred, IMGs attributed it to patients' illness, age, or other problems with interaction, rather than them being difficult or unfair.

Colleagues shared examples of how working with an IMG who did not communicate well with patients influenced the whole workday. As described by one doctor: "If he had been on rounds, I sometimes asked patients afterwards if there is something they are wondering about; usually there is. Then I have to explain it. I have been together with the IMG doctor at rounds; I listen but see that it is obvious that patients do not understand. Afterwards I go back to the patient and explain what the doctor meant; I often do that" (Senior Doctor, small local hospital). Colleagues found it especially difficult to cooperate with IMGs who did not take into account their own communication limitations, yet they admitted rarely commenting directly on the IMGs' language themselves. These accounts suggest wider effects of language barriers than just difficulties with understanding, revealing implications for relationships, clinical quality, and thoughts about self-efficacy. 


\section{Discussion and conclusion}

\subsection{Discussion}

Literature shows that both IMGs [6,7,10-12,19,35] and colleagues of IMGs [12] experience language barriers. The results from this study reveal that IMG and Norwegian health care providers have concerns regarding a number of topics that could be considered language barriers; therefore, remediation relies on a multifaceted approach. In addition, language shortcomings by both participant groups were associated with feelings of insecurity during interactions and potential loss of self-esteem for IMGs.

IMGs are an important part of the workforce in many countries [1,2], but knowledge of how to facilitate IMG training and language skills is incomplete [14]. The language barriers participants described do not have clear associations with the IMGs' nationality or position. This illustrates that IMGs are individuals, and language barriers are contextual and multifaceted, involving aspects that are more complex than language issues alone. Indeed, an interesting finding in our study is that what participants described as merely language barriers actually included a range of topics that included semantics, pragmatics, and cultural aspects of language use (Table 3), encompassing much of what they experienced as difficult or different in their everyday collaboration. These findings indicate that courses limited to a focus on language skills do not (and will not) meet their needs. Our conclusion that such a limitation exists is further supported by IMGs, who reported that general Norwegian classes were inadequate for addressing their professional communication needs; even doctors from neighboring countries requested relevant work-related language courses because of the complexity and multiple contexts related to doctor-language. This necessity is supported by well-established research on second language learning, showing that language learning associated with learners' everyday life is often felt necessary and therefore often becomes effective [36]. Participants reported that arrangements that address both language issues and issues around being a new doctor in Norway do not currently exist, neither formally nor informally. Instead, each individual IMG is left alone, to learn both the Norwegian language and gradually figure out, through trial and error, their new role as a doctor. As a result, both colleagues and IMGs struggle to address and overcome what they perceive as language barriers.

Working as a doctor in a new country is often described as being demanding and emotionally stressful $[6,21,37]$. This study shows that language barriers are an important stressor. All participants reported that language barriers were intertwined with uncertainty about an IMGs' competency as a professional Norwegian doctor. One reason for an association between language difficulties and competency could be that professional communication skills are important for patient safety and an essential element in enhancing patient satisfaction [31]. It is important to note that our data contain 
few descriptions linking language barriers to serious incidents, yet both IMGs and colleagues described many situations where IMGs did not meet their own or others' expectations of a doctor's professional communication skills. An additional factor that may lead to questions about professionalism has been revealed in basic research on perceptions of non-native speakers with accented speech, who are generally considered by members of the majority population as less credible than those who speak Norwegian fluently, even when the content of their speech is accurate [38]. It is possible that a doctor who is not a native speaker, simply by virtue of his or her accent (i.e., not actual medical competence), can both be perceived by others and themselves as less competent. Further, the kinds of language difficulties that informants described involve interpretive processes that can lead to misunderstandings that cast the IMGs in an unflattering light, perhaps making them appear uncooperative or unfriendly [34]. We found that colleagues felt that IMGs understated their own language shortcomings, a phenomenon supported by other research as well [12]. Both IMGs' and colleagues' experiences support the need for training that offers the IMGs the ability for reflection so that they can gain an insight into their own language skills and role as a Norwegian doctor.

The identity of being a doctor is strong, whether the doctor is an IMG or not $[39,40]$. A recurring theme in all interviews was that for IMGs, a language barrier created a "sense" of not living up to their own ideals of being a professional doctor. Also, native Norwegian colleagues implicated language barriers to IMGs' competence in handling everyday work. In literature on what it means to be a professional, main elements include having the right knowledge and sets of skills [41]. In modern health services, such skills include handling professional communication and collaboration. The IMGs were formally licensed to practice medicine as doctors in Norway, and their employers considered their language skills as adequate for practice. However, compared to what Edmund describes as important factors for being considered a professional, several IMGs considered themselves to be outsiders who fall short of the ideal: "It is not just about demonstrating a meeting of standards in practice. It is about relationships with colleagues and participating in and contributing to the development of professional communities" [42]. Participants provided several examples of how IMGs' insufficient Norwegian language skills affected their participation within their peer community, feeling that their participation was inadequate. Most of the participants also described how language barriers made changes in their everyday practice. Norway and several other countries worldwide are in need of IMGs. This study from a Norwegian setting indicates that to successfully overcome language barriers, IMGs require a system to support their adaption and learning. Neglecting such supports seems to be stressful for both IMGs and their colleagues. Moreover, professionals' ability to provide good care has been shown to be dependent on well-functioning communication and effective role management [43], both of which become vulnerable without system support. In the multilingual context of Norwegian healthcare, care must be taken that the IMGs are not dealt a double blow of being inadvertently penalized for their low linguistic capital while being offered neither the means for 
identifying and remediating language difficulties nor socialization into their Norwegian workplace[44].

This study was exploratory and several limitations affect interpretation of the results. One limitation is that it focused mainly on IMGs' work life. From a cultural perspective, in order to explore the IMGs' identities, their life outside the workplace should be taken into consideration. Other studies have shown that IMGs may misjudge their own communication skills [12,45]. A limitation of this study is that it did not address how IMGs' experiences concord with their actual language skills and ability to communicate as healthcare professionals in Norway, though all IMGs struggled with Norwegian language skills in the interview. Finally, the interviews could have been more extensive, exploring more in depth how both groups of participants' experiences and views were influenced by their values and their way of seeing the world.

Nonetheless, interviews are suitable for providing insight into the participant's experiences and self-understanding [30]. This study did not aim to present an exhaustive knowledge about language barriers, but instead, its aim was to describe some elements that could be important for better integration and language learning for IMGs. The main strength of the study is that IMG and colleague participants who worked in a wide range of Norwegian health services provided similar practical examples and reflections about the topic. The findings were consistent with regard to their experiences, concerns, and understanding of the phenomena of professional communication and communication barriers. Furthermore, the study opened some doors to unknown territory that not only contribute a new understanding of that territory, but also show that deeper exploration could be fruitful.

\subsection{Conclusion}

Newly employed IMGs and their colleagues experienced that a lack of proficiency in the working language brought the new IMGs' professional competency and professionalism into question. Lack of language proficiency, included a range of underlying challenges, such as the lack of familiarity with the healthcare system, expectations for the role of both doctor and patient, specific subject area knowledge, and ritual and cultural expressions necessary to provide adequate care. Our findings reveal that IMGs' learning needs are not only about learning the language, but also about how to adapt to their current situation and new work context. For most IMGs, this learning process seems to involve redefining their identities as professional doctors and communicators, a process that in Norwegian health services has been left to the new IMGs to facilitate for themselves.

\subsection{Practice Implications}

To counteract experiences of psychological stress and insufficient communication that could lead to possible mistakes or misunderstanding, the findings in this study indicate that IMGs need continued professional language training after they have started working. Such training should be 
multi-faceted, including specific communication skills related to the IMGs' work context and ongoing, professional mentoring targeted to the needs that our participants revealed. Effective language and communication training should allow reflection on individual concerns and experiences.

\section{Acknowledgements}

The Norwegian Research Council funded this work (grant number: 204548, 2010).

We acknowledge Sissel Steihaug (MD, PhD) for patient method guidance in all parts of this study and critical comments that improved this paper.

\section{References}

[1] F. Mullan, The metrics of the physician brain drain, N Engl J Med. 353 (2005) 1810-8.

[2] P.G. Herfs, Aspects of medical migration with particular reference to the United Kingdom and the Netherlands, Hum Resour Health. 12:59 (2014) 1-7.

[3] E. Diaz, S. Hjørleifsson, Immigrant general practitioners in Norway: a special resource? A qualitative study, Scand J Public Health. 3 (2011) 239-44.

[4] I. Drange. A study of labour market careers for professionals of ethnic minority origin. Thesis (ph.d.) Oslo, Høgskolen i Oslo og Akershus, 2013.

[5] A. Taraldset, [Forieng doctors in Norway 2001-2010], Utenlandske leger i Norge 2001-2010 Fagtidsskriftet Helse/Medisin/Teknikk (HMT) 6(2010) 16-9.

[6] M. Bretthauer, [Do you understand me?], Forstår du meg?, Tidsskr Nor Laegeforen. 129 (2009) 2211.

[7] M.R. Dahm, Patient centred care - are international medical graduates 'expert novices'?, Aust Fam Physician. 40 (2011) 895-900.

[8] J.A.M. Harmsen, R.M.D. Bernsen, M.A. Bruijnzeels, L. Meeuwesen, Patients evaluation of quality of care in general practice: What are the cultural and linguistic barriers?, Patient Educ Couns. 72 (2008) 155-62.

[9] N. Berbyuk Lindström. Intercultural communication in health care. Non-Swedish physicians in Sweden, Gothenburg, Gothenburg monographs in linguistics, 2008.

[10] L.S. Pilotto, G.F. Duncan, J. Anderson-Wurf, Issues for clinicians training international medical graduates: a systematic review, Med J Aust. 187 (2007) 225-8.

[11] R. Woodward-Kron, C. Fraser, J. Pill, E. Flynn, How we developed Doctors Speak Up: an evidencebased language and communication skills open access resource for International Medical Graduates, Med Teach. 37 (2015) 31-3.

[12] A.U. Mitchell, F.H. Tabaei, D. Ostergaard, M. Freil, [Conditions for foreign doctors' clinical work assessed by Danish health care personnel, patients and foreign doctors], Ugeskr Laeger. 170 (2008) 1833-8.

[13] M. Hull, Medical language proficiency: A discussion of interprofessional language competencies and potential for patient risk, Int J Nurs Stud. 54 (2016) 158-72.

[14] M. Lineberry, A. Osta, M. Barnes, V. Tas, K. Atchon, A. Schwartz, Educational interventions for international medical graduates: a review and agenda, Med Educ. 49 (2015) 863-79.

[15] R.J. Schwei, S. Del Pozo, N. Agger-Gupta, W. Alvarado-Little, A. Bagchi, A.H. Chen, et al., Changes in research on language barriers in health care since 2003: A cross-sectional review study, Int J Nurs Stud. 54 (2016) 36-44. 
[16] J.W. Berry, Acculturation: Living successfully in two cultures, International Journal of Intercultural Relations. 29 (2005) 697-712.

[17] J.W. Berry, Stress perspectives on acculturation, in: D.L. Sam, J.W. Berry, (Eds.), The Cambridge handbook of acculturation psychology, Cambridge University Press, Cambridge, 2006, pp. 43-57.

[18] U.G. Småland Goth, J.E. Berg, Migrant participation in Norwegian health care. A qualitative study using key informants, European Journal of General Practice. 17 (2010) 28-33.

[19] E. Skjeggestad, G.M. Sandal, P. Gulbrandsen, International medical graduates' perceptions of entering the profession in Norway, Tidsskr Nor Laegeforen. 135 (2015) 1129-32.

[20] J.H. Bernstein, The professional self-evaluation of immigrant physicians from the former Soviet Union in Israel, J Immigr Health. 2 (2000) 183-90.

[21] G. Kalra, D.K. Bhugra, N. Shah, Identifying and addressing stresses in international medical graduates, Acad Psychiatry. 36 (2012) 323-9.

[22] A. Atri, A. Matorin, P. Ruiz, Integration of international medical graduates in u.s. Psychiatry: the role of acculturation and social support, Acad Psychiatry. 35 (2011) 21-6.

[23] K. Fiscella, R. Frankel, Overcoming Cultural Barriers: International Medical Graduates in the United States, JAMA: The Journal of the American Medical Association. 283 (2000) 1746-51.

[24] A. Wong, L. Lohfeld, Recertifying as a doctor in Canada: international medical graduates and the journey from entry to adaptation, Med Educ. 42 (2008) 53-60.

[25] M.G. Pratt, K.W. Rockmann, J.B. Kaufmann, Constructing Professional Identity: The Role of Work and Identity Learning Cycles in the Customization of Identity Among Medical Residents, Acad Manage J. 49 (2006) 235-62.

[26] I. Wilson, L.S. Cowin, M. Johnson, H. Young, Professional Identity in Medical Students:

Pedagogical Challenges to Medical Education, Teach Learn Med. 25 (2013) 369-73.

[27] J. Paterson, J. Higgs, S. Wilcox, M. Villeneuve, Clinical reasoning and self-directed learning: key dimensions in professional socialisation, Focus on Healt Professional Education. 4 (2002) 5-21.

[28] C. Reynolds, Cultural scripts for teachers: Identities and their relation to workplace landscapes, Changing research and practice: Teachers' professionalism, identities and knowledge. (1996) 69-77. [29] K. Malterud, Systematic text condensation: A strategy for qualitative analysis, Scandinavian Journal of Public Health. 40 (2012) 795-805.

[30] S. Kvale, Interviews : an introduction to qualitative research interviewing, Thousand Oaks, Calif, Sage, 1996.

[31] M.S. Donaldson, L.T. Kohn, J. Corrigan, To err is human : building a safer health system, Washington, National Academy Press, 2000.

[32] K. Malterud, Qualitative research: standards, challenges, and guidelines, The Lancet. 358 (2001) 483-8.

[33] A. Giorgi, The descriptive phenomenological method in psychology : a modified Husserlian approach, Pittsburgh, Pa., Duquesne University Press, 2009.

[34] J.J. Gumperz, Discourse strategies, New York, Cambridge University Press, 1982.

[35] P. Gulbrandsen, T.V. Schroeder, J. Milerad, T. Nylenna, [Do Scandinavian physicians understand each other's languages?], Forstår skandinaviske leger hverandre?, Tidsskr Nor Legeforen. 121 (2001) 2042-4.

[36] B. Peirce, Social identity, Investment, and Language-Learning, Tesol Q. 29 (1995) 9-31.

[37] K. Fiscella, M. Roman-Diaz, B.H. Lue, R. Botelho, R. Frankel, 'Being a foreigner, I may be punished if I make a small mistake': assessing transcultural experiences in caring for patients, Fam Pract. 14 (1997) 112-6.

[38] S. Lev-Ari, B. Keysar, Why don't we believe non-native speakers? The influence of accent on credibility, J Exp Soc Psychol. 46 (2010) 1093-6.

[39] L. Remennick, G. Shakhar, You Never Stop Being a Doctor: The Stories of Russian Immigrant Physicians Who Converted to Physiotherapy, Health:. 7 (2003) 87-108.

[40] E. Neiterman, I.L. Bourgeault, Conceptualizing Professional Diaspora: International Medical Graduates in Canada, Journal of International Migration and Integration. 13 (2012) 39-57. 
[41] F. Trede, R. Macklin, D. Bridges, Professional identity development: a review of the higher education literature, Studies in Higher Education. 37 (2012) 365-84.

[42] N. Edmond, The role of $\mathrm{HE}$ in professional development: some reflections on a foundation degree for teaching assistants, Teaching in Higher Education. 15 (2010) 311-22.

[43] K.M. Sutcliffe, E. Lewton, M.M. Rosenthal, Communication failures: an insidious contributor to medical mishaps, Acad Med. 79 (2004) 186-94.

[44] C. Roberts, Language Socialization in the Workplace, ARAL. 30 (2010) 211-27.

[45] M. Sandbu, A. Kamps, V. Preljevic, C. Javo, Foreign doctors in Norwegian psychiatry - is there a need for a mentoring scheme?, Tidsskr Nor Laegeforen. 135 (2015) 1133-7. 